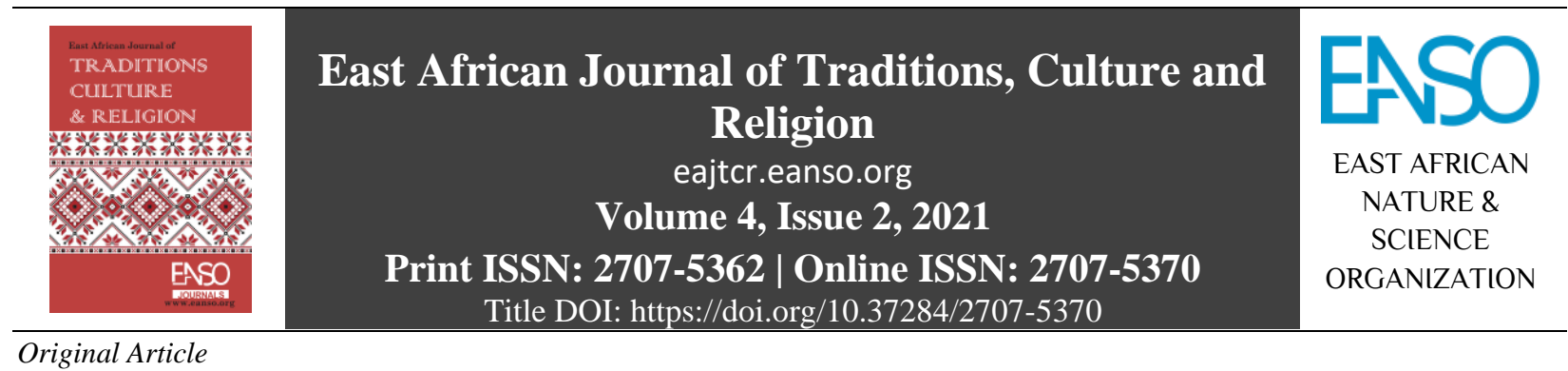

\title{
Ubuntu Philosophy as a Technology for the Foundational Architecture of African Ecclesiology in Reference to Harvest Revival Ministry Churches in Kenya.
}

\author{
Peter Lee Ochieng Oduor, PhD \\ ${ }^{1}$ Africa International University, P.O Box 24686, 00502, Nairobi, Kenya. \\ Author Correspondence Email: pastoroduorlee@gmail.com.
}

Article DOI: https://doi.org/10.37284/eajtcr.4.2.487

\begin{abstract}
Date Published: ABSTRACT
29 November 2021 The study seeks to study the Christian narrative unearthing the wealth of resources inherent in it to act as a stimulant and a motivating force for the

Keywords: present church towards the much-desired immortality that is the mark of the finish. It is an account that dates back to the first century during the

Ubuntu, formation of the church to the present state of the church in her pursuit of Philosophy, an alignment to the eschatological roadmap stipulated in scriptures. The Technology, study employs the scholarship of the historical Christian narrative from the Architecture, analogical perspective of a journey of the Israelites in the Pentateuch towards Canaan. This was a journey that was characterized by pulsations of Contextualization, moving and stopping based on the instruction and guidance of God. African Ecclesiology, Similarly, the Christian story is one that is emphatic with regard to the Ecclesiolatry involvement of God in the Christian journey. The study captures the dominant moves of God over the centuries and their significant contribution to the establishment and progress of Christianity and the key players in the entire process from the protestant movement to the Apostolic Reformation. This will facilitate the understanding of the church in her present state as a product of her past journey and development with regard to offering guidance and facilitation of Christian practice. It will help the church with regard to guidance to help her avoid falling into the pit that their forerunners fell into and also motivate her towards greater exploits for God.
\end{abstract}

\section{APA CITATION}

Oduor, P. L. O. (2021). Ubuntu Philosophy as a Technology for the Foundational Architecture of African Ecclesiology in Reference to Harvest Revival Ministry Churches in Kenya. East African Journal of Traditions, Culture and Religion, 4(2), 111. https://doi.org/10.37284/eajtcr.4.2.487.

\section{CHICAGO CITATION}

Oduor, Peter Lee Ochieng. 2021. "Ubuntu Philosophy as a Technology for the Foundational Architecture of African Ecclesiology in Reference to Harvest Revival Ministry Churches in Kenya.”. East African Journal of Traditions, Culture and Religion 4 (2), 1-11. https://doi.org/10.37284/eajtcr.4.2.487.

1 | This work is licensed under a Creative Commons Attribution 4.0 International License. 


\section{HARVARD CITATION}

Oduor, P. L. O. (2021) "Ubuntu Philosophy as a Technology for the Foundational Architecture of African Ecclesiology in Reference to Harvest Revival Ministry Churches in Kenya.”, East African Journal of Traditions, Culture and Religion, 4(2), pp. 1-11. doi: 10.37284/eajtcr 4.2.487.

\section{IEEE CITATION}

P. L. O. Oduor, "Ubuntu Philosophy as a Technology for the Foundational Architecture of African Ecclesiology in Reference to Harvest Revival Ministry Churches in Kenya.", EAJTCR, vol. 4, no. 2, pp. 1-11 Nov. 2021.

\section{MLA CITATION}

Oduor, Peter Lee Ochieng. "Ubuntu Philosophy as a Technology for the Foundational Architecture of African Ecclesiology in Reference to Harvest Revival Ministry Churches in Kenya." East African Journal of Traditions, Culture and Religion, Vol. 4, no. 2, Nov. 2021, pp. 1-11, doi:10.37284/eajtcr.4.2.487.

\section{INTRODUCTION}

That Jesus Christ is in the business of building His church on a firm foundation is a theme strongly advanced by the New Testament writers. Jesus in His own words stated that "...on this rock, I will build my church, and the gates of Hades will not overcome it" Mathew 16:18. The architectural design of the church that Jesus is building is articulately captured in the New Testament whose authors emphasized specific virtues as identifiers of the newly established community called church. Among the key features that signified this newfound community under the Lordship of Jesus were key integral traits that were identical to the traditional African setting that cemented the community bond.

The African way of life embedded in the African philosophy of Ubuntu that transcended all spheres of African life to the extent that it is virtually impossible to talk of African philosophy without talking about Ubuntu largely because the two are intricately linked hence they are two sides of the same coin as stated by Munyaradzi Mawere \& Tupuwa R. Mubaya (2016, p. 100). This philosophy was responsible for the unity and strength of African communities. The philosophy has its bottom-line in the ontological understanding of humanity from the African perspective. It is in this spirit of contextualization that this study would wish to give advocacy to the Ubuntu parameters from the African way of life as key ingredients for a stable ecclesiological conversation resulting in the establishment of churches in Africa that appreciate the African ethos and answer the questions raised by Africans. To achieve this end the study will seek to explain the philosophy of Ubuntu, African ecclesiology, and Harvest Revival Ministry Churches in Kenya from now referred to as HRM; highlight some key practical dimensions of the
Ubuntu Philosophy and their scriptural sanctions; examine their foundational characteristic and value to the HRM and by extension African ecclesiology; and finally submit conclusion and recommendations.

\section{Understanding the African Ubuntu Philosophy}

To properly study the African Ubuntu Philosophy, we need to look at two areas: firstly, the understanding of what philosophy is all about; and finally, the concept of Ubuntu as a philosophy. Scholarship of philosophy exposes us to the ambiguity that philosophers have had with regard to according philosophy an accurate definition. Dewey (2012, p. 378) observes that whenever philosophy has been accorded high-level seriousness it has been assumed to signify achieving wisdom that would influence the conduct of life. From another perspective, philosophy is considered as a critical method of approaching experience according to Shivendra Chandra (2006, p. 4). The word philosophy originates from the Greek word philo and Sophia translated to mean the love of wisdom bearing the connotation of more than the acquisition of intellectual grasp of the big questions of life as it entails gaining insights culminating to a life well lived as the objective of philosophers goes beyond thinking well to living virtuously as correctly stated by (Cowan \& Spiegel, 2009, p. 2). Rosenberg (1978, p. 4) defines philosophy as something that people do as a practice and as a practice, it is an activity of research. The observation of different definitions of philosophy we infer that philosophy is basically man's effort to investigate reality or truth through rational or empirical means and is the search for knowledge in general about God, man,

2 | This work is licensed under a Creative Commons Attribution 4.0 International License. 
and the created order of the universe as is articulated by Pam (2012, p. 28).

In the same measure that granting a singular definition to the concept of philosophy has proven elusive among philosophers, there have also been divergent views on the latitude of the discipline. Craig (2009, p. 12) acknowledges this in the expression that the scope of the word philosophy has varied considerably through history, not to mention that there has never been a time it meant the same thing for everyone. Munyaradzi (2016, p. 6) acknowledges that philosophy has been spoken of as a way of life both for the individual and group to the extent that it has become difficult to determine who is a philosopher and who is not, and based on that it is conclusive to state that everyone has a philosophy if they have a way of life. Akinpelu (1981, p. 2-3) attempts to clarify and simplify the composition of philosophy through an approach of observing two senses of philosophy: common or popular philosophy is taken to refer to one's attitude to life which is as a result of one's assumptions, beliefs, attitudes, and prejudices to things; professional or technical sense refers to philosophy as an academic discipline in which scholars devote their time and energy.

This brings to the attention of this study the need to accord some time to the understanding of an African philosophy because the concept of Ubuntu has been conceptualized as a philosophy of the African people. The mention of African philosophy has elicited a heated argument among the academia with three categories of response according to the evaluation of Lajul (2014, p. 2): the first category doubt the existence of African philosophy; the second category accept the idea of African philosophy but uncritically equate proverbs, folktales, and other African value systems to philosophy; lastly are those of the belief that it is high time for Africans to develop and show the world the existence of world view, systems of governance, and way of behaviour informed or based on identifiable theories, principles and consistent explanations that are not necessarily equated by other non-African ways of looking at things.

Father Placide Frans Tempels and colleagues (1959, p. 21) acknowledged as the pioneer of the conversation of Bantu (African) Philosophy questions if the Bantu philosophy has been enveloped and studied as such and the need of all scholars to seek out and define the fundamental thought underlying Bantu ontology the only key that allows native thought to be penetrated. It is this existing ontology that penetrates and informs all the thoughts of these primitives dominates and orients all their behaviour according to (Tempels et al., 1959). Masolo (1994, p. 47) notes that according to Tempels, the entire system of Bantu thought based on this ontology is philosophy even as he acknowledges the difficulty to convince his (Tempels') readers who were missionaries and colonial administrators. Imbo (1998, p. 11) further affirms that according to Tempel despite criticism as to why he was the one behind the formulation of the Philosophy without the involvement of the Bantu, he affirmed that the proof that complex ontological ideas are indeed held implicitly by the Bantu is that when he submitted his formulation of Bantu Philosophy to the people themselves, they agreed that he had correctly stated what they meant.

Another contributor to the conversation of African philosophy was one; Leopold Sedar Senghor a Senegalese statesman credited for crafting a negritude theory another variation on the theme of ethnophilosophy in the sentiments of (Imbo 1998). On the same note, Imbo (1998, p. 12) acknowledges that Senghor grounded his socio-political philosophy of negritude in the idea that the African experience of the world is based on emotions, not reason. The emphasis of negritude was a consciousness of the world through the medium of emotion, and the expression of emotion is at the centre of African culture and that Africans in their languages, experiences, and cultures demonstrate a distinct mode of apprehension holding that Africans were different from but not inferior to Europeans thus he led the negritude movement of philosophers, anthropologists, and poets in defending an unscientific, unanalytical and untechnical African mind as it is captured by (Imbo, 1998).

Alexis Kagame (1919-1981) a Roman Catholic priest from Rwanda also significantly contributed to linguistic ethnophilosophy emending Tempels' ontology through his linguistic analysis of the Rwandan language, affirming an African difference, and suggesting an 'original formative 
environment' unique to the African mode of thinking in light of Ochieng' et al. (2008, p. 124). This study is in agreement with the Journal of Theology for Southern Africa (2007) that to this end, ethnophilosophers have been on the forefront to make a bold statement especially directed to their European counterparts that Africans have their system of thought that reveals a system of the philosophy of religion and of cosmology similar to that of Europeans and it is rightly referred as 'Ethnophilosophy' because of its spirited endeavour to translate the African ethic thought into categories and language of Western philosophy with chief proponents as John Mbiti of Kenya, Alexis Kagame of Rwanda, Tempels and Marcel Griaule of France. Munyaradzi (2016, p. 100) to capture Ubuntu as the moral compass of the African people, affirms that the Ubuntu concept since time immemorial shapes and guides the African world view in its entirety and that all the branches of African philosophy are in one way or another influenced by Ubuntu therefore significantly raising Ubuntu as a major moral aspect in Africa.

\section{CONCEPTUALIZING AFRICAN ECCLESIOLOGY}

To accurately conceptualize African ecclesiology, we first examine the concepts of ecclesiology and contextualization. The New Testament Greek word

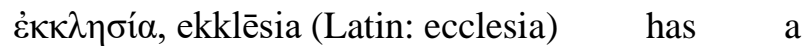
connection with the Hebrew terminology qahal (that

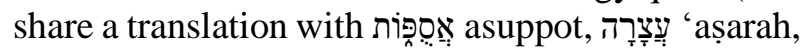

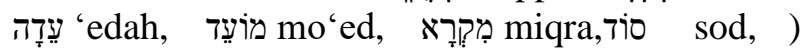
translated in the English words, congregation, assembly, company, etc. in light of (Pam, 2012, p. 392). Peck (1892, p. 14) defines the church as a society of faithful or believing men, called by God through the Word, out of the whole human race, to the communion of the covenant of grace in Christ. From this definition of the church, we can ascertain that there is a threefold theological component attached to it: a community instituted by God himself; a community of faith and obedience; and a community of faith and obedience which lives from God's word as captured by (Barth, 2015, p. 334). We can therefore affirm that ecclesiology bears the connotation of the discourse about the doctrines about the church in general. The renaissance of ecclesiological scholarship has been a result of the ecumenical movement as there has been no other movement in the history of the Christian church, perhaps with the exception of Reformation, that has shaped the thinking and practice of Christendom as much as the modern movement of Christian unity according to (Kärkkäinen, 2002, p. 7-8).

Another catalyst triggering the renaissance of ecclesiological thinking and conversation is the speedy and sparodic growth of Christianity outside the West, so much that currently, the majority of Christians are in the two-thirds world as is captured correctly by Kärkkäinen (2002, p. 8). Jenkins (2002, p. 1) in agreement analyses that the last century witnessed a shift in the centre of gravity of the Christian world from Europe, southwards to Africa and Latin America and eastwards towards Asia, habouring the largest Christian communities on the planet. Volf (1998, p. 9) acknowledges the factor of Free Churches as a contributing factor to the emergence of ecclesiological studies with the free churches designating churches with a congregationalist church constitution and those that affirm a consistent separation of the church and the state. Avis (2019, p. 1) places academic ecclesiology at the forefront of modern theological attention stating that ecclesiology has become a major theological discipline as it remains at the centre of theological research and debate.

With this resurgence of ecclesiology especially as an independent entity in theological studies, there has been a variety of approaches that ecclesiological scholarship has undertaken. One notable approach especially among eccumenical settings is the comparative ecclesiological approach that takes a route of examining the systematic reflection on the points of similarity and differences in the ecclesiologies of the divergent denomination as has been defined by Dulles (1974, p. 7). Kärkkäinen (2002, p. 14) is quick to capture the two-fold sources that comparative ecclesiology so heavily relies on as the official denominational confessional writings and the texts from representative theologians that represent their respective denominational affiliations. The recent phenomenon of the shift in the centre of Christianity from the North to the global South has resulted in an emergence of a peculiar approach of conducting ecclesiology. Kärkkäinen (2002) acknowledges that this approach focuses on what has been conveniently described as

4 | This work is licensed under a Creative Commons Attribution 4.0 International License. 
contextual ecclesiologies and in some quarters global ecclesiologies.

This global ecclesiology intends to address these regions in the global South that have a strong Christian presence such as Asia, Latin America, and Africa in an effort to contextualize ecclesiology in these specific settings. Contextualization begins from the assumption that every theology is shaped by its particular context and must be so to be relevant and meaningful and is forthright in relating the Christian message to all social contexts and cultures especially including those that undergo rapid change as captured by Allan Anderson in (Wonsuk Ma et al., 2004, p. 135). Gilliland in A. Scott et al. (2000, p. 225), states that the goal of 'contextualization' is to enable, insofar as it is humanly possible, an understanding of what it means that Jesus Christ, the Word, is authentically experienced in each and every human situation. He further alludes to the fact that the Christian message must be proclaimed in the framework of the worldview of the particular people to whom it is addressed, it must emphasize those parts of the message that answer their particular questions and needs, and it must be expressed through the medium of their cultural gifts. Scholarship of ecclesiology from a global perspective is intentional in unearthing the cultural-geographical contexts that are in existence from different regions. African ecclesiology falls in this category that is keen to articulate African philosophy captured in her values and ethos in the conversation and debate as a platform to the conversations and practice of ecclesiology in Africa.

\section{HARVEST REVIVAL MINISTRY CHURCHES IN KENYA (HRM)}

Harvest Revival Ministry (HRM) is a duly registered church society in the republic of Kenya since 2013. It is a Pentecostal church that is indigenous in orientation but shares a close relation to Yoido Full Gospel Church (YFGC) in South Korea that is her mother organization. Young-hoon Lee has acknowledged that as the Korean church in South Korea grew explosively in the 1970s, the YFGC captured the attention of the world and it was pastored by Rev. David Yonggi Cho and had a membership of 700,000 by the end of 1994 and was viewed as a base of the Pentecostal movement in
Korea having been founded in 1958 as documented by (Wonsuk Ma, 2004, p. 1). One of the emphases of YFGC has been to extend God's love to the lower class and the underprivileged in the society by engagement in the broad charity work through the instruments of evangelism and world mission that has seen various mission groups and committees participate in evangelical programs as described by Young-hoon Lee. South Korea sends more missionaries than any country but the U.S.A and it will not be long before its number one according to the analysis of Moll (2006) in the article dubbed 'missions incredible' published in Christianity

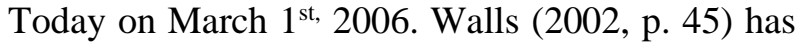
acknowledged that the great missionary nation is now Korea as in every continent there are Korean missionaries by the hundreds, and his projection is that in the coming years we can expect hundreds more, preaching from Tashkent to Timbuktu, and reaching where Westerners have long been unable to tread.

The mission agency in YFGC known as World Mission Department supports Cho's foreign campaigns, sends missionaries, and establishes and supports foreign Bible schools to the extent that as of 2003, YFGC has sent 600 missionaries, and established seven Bible seminaries and one University, and expanded its missionary work in the two-thirds world according to Wonsuk Ma et al. (2004, p. 11). Kenya has also been a beneficiary from this effective missionary strategy to this as missionaries from YFGC in Kenya work under Dr. David Yonggi Cho's Africa Mission Centre registered as a missionary agency in this republic. The missional strategy of YFGC as is captured by Young-hoon Lee in Wonsuk Ma et al. (2004) is the establishment of Bible seminaries in the mission fields to raise native pastors and Christian leaders to evangelize their own countries. There are seminaries and Bible colleges in Malang (Indonesia), Nairobi (Kenya), Chimkent (Uzbekistan), Hong Kong (China), Tel Este (Bolivia), Osaka, and Tokyo (Japan). The Kenya Bible College is stationed in Karura Kanyungu in the suburbs of the Capital City, Nairobi, and is known as the Youngsan Bible College (YBC). The YBC has been in existence since the year 2000 and continues to train ministers from different countries in the continent to be more effective in their service to God and humanity. Harvest Revival Ministry 
(HRM) is one among the many fruits of this missional endeavour of YFGC as a daughter church in Kenya as they share an identity of associating with YFGC as her mother organization.

More than fifty percent of the pastoral staff of HRM Churches have undergone the pastoral training program in YBC with twenty-five percent of the pastoral staff currently enrolled in the program thus the large-scale similarity between HRM Churches and YFGC with regard to doctrine and practice. The main reason for the rapid growth of YFGC was the great moving of the Holy Spirit, resulting in Yonggi Cho's doctrine of the 'Fivefold gospel' and the 'Threefold Blessing' with the 'Fivefold gospel' being the theological theory and doctrine whereas the 'Threefold Blessing' is the practical application of it, this lead Yonggi Cho out of creativity to construct the doctrinal essence of Full Gospel Theology according to the analysis of Andersson \& Tang (2005, p. 533). Home cell groups remain the trademark for YFGC and is fondly rrferred to as the smallest church in the world as well as the biggest in church history because every member of the church is part of a home cell group consisting of ten to twenty people in the words of Myung (1998, p. 132). Myung and Hong (2003, p. 144) agree that this cell system is a strong point of YFGC serving as agencies of evangelism, care, spiritual maturation, and fellowship. HRM Churches have borrowed the concept of cell church and doctrine from YFGC together with the Friday night prayer vigil as core practical mechanisms to steer the churches towards both physical and spiritual growth. HRM churches are in Taita, Trans Nzoia, and Bungoma counties with plans to expand and plant churches in other regions in the Republic of Kenya

\section{COMPONENTS OF UBUNTU PHILOSOPHY BENEFITING AFRICAN ECCLESIOLOGY}

Philosophy arises from a people's language anywhere and is found wherever there are human beings expressing their deepest concerns, interests, and aspirations and where there is sufficient critical reflection on how best to give reflection to these concerns, interests, and aspirations as is expressed by (Bell \& Fernback, 2015, p. 4). There is the general consensus among Bell and Fernback (2015) that understanding African philosophy is dependent on the state of preparedness to see the world in new ways and express appreciation of what they are seeing. As opposed to Western liberal democracy that assumes people to be atomized individuals, the African philosophy of Ubuntu places the Self at its centre whereby the Self not only consists of the physical individual but also includes the social environment with which we identify because without other people a person can never be fully human as correctly captured by Zandberg (2010, p. 7). To capture the contrast that exists with the Eastern philosophy Zandberg (2010) asserts that Eastern philosophy takes people and their social environment into its reasoning, but they place people as being part of their environment while in the Ubuntu philosophy the social environment is part of people. Shutte (2002, p. 8-9) explains how the Ubuntu philosophy falls short of being individualistic, in the manner in which liberalism and capitalism are attempting to liberate the individual by separating them from the community; neither is it collectivist like communism or first world socialism that makes the individual just a part of the community but for Ubuntu philosophy a person depends on persons to be persons. Thus by belonging to the community that we become ourselves because the community is not opposed to the individual now does it simply swallow the individual up but enables each individual to become a unique centre of shared life. To attempt to research the vast African philosophy of Ubuntu would take more than an entire book and consequently, our study would capture two elements inherent in the notion of Ubuntu that is foundational to African ecclesiology by observing HRM Churches.

\section{A People Centred Philosophy}

The ministerial philosophy of HRM Churches places the essence and significance of people above all assets both movable and non-movable. People matter more than the programs and structures because all exist for the benefit of the people. This is the reflection inherent upon the African philosophy of Ubuntu that is mystically anthropocentric placing human beings at the centre of all things meaning that people matter more than things as is emphasised by Adeyemo (2009, p. 16). This approach of ecclesiology is keen on her emphasis on the priopritization of the church membership as the centre of her ecclesiology. This is accelerated by an accurate understanding of the

6 | This work is licensed under a Creative Commons Attribution 4.0 International License. 
meaning of ecclesiology and the concept of ecclesiality. Luther was keen to emphasize that the church was first and foremost a communion of the saint and a gathering of believers and share a calling of the Holy Spirit as is documented by Kärkkäinen (2002, p. 39-40). The emphasis of the African ecclesiological conversation cannot miss out on that understanding of prioritizing people in her quest to come up with an elaborate ecclesiology that is relevant to the African ethos. In a dispensation that thrives on a materialistic approach that seems to be more popular and marketable, the African ecclesiology should not degenerate into the valuation of the stability and progress of the church along with all other matters apart from the stability and progress of the congregants with regard to aligning their lives and practice to the will of God.

HRM Churches are keen to have as their foundational architecture, internal values that should be incumbent on all her membership to facilitate the flow of grace into the lives of every single member of her congregation. This is akin to sensitizing all of the significance of their contribution and participation regardless of their tribe, race, gender, status, or any other factor that may be segregational. By his concept of the priesthood of all believers, Martin Luther advocated for widened boundaries of the spiritual estate beyond the monastic and clerical orders towards an all comprising audience that incorporated all to the exclusion of none as is captured by (Harran, 1997 p. 270). Luther tenaciously supported the non-institutional character of the church with strong displeasure of the word Kirche with a stronger preference to terminologies as Sammlung (assembly) and Gemeinde (congregation) because he believed that Ecclesiolatry centred on the gathering of believers as is articulated by Kärkkäinen (2002). The peoplecentred ideology is one that prioritizes the task of bringing all on board for a constructive engagement that is an essentiality for African ecclesiology akin to her quest of constructing self-supporting, selfgoverning, and self-propagating churches. HRM Churches has embraced the African philosophy of Ubuntu by the emphasis on the internal value of care among all her congregants. This is the reason for her adoption of the cell church approach and people groups to activate the virtue of care from every member. Caring is a key element of Ubuntu because no individual lives for him or herself alone and is the intrinsic sense of obligation where people care regardless of an acquaintance or non- acquaintance to the person in need as captured in the sentiments in (Resane, 2017 p. 107). To nurture this internal value of care, attribute the HRM Churches leadership embarks on training and empowerment of her constituents to actively participate in the task of meeting the needs of their brethren.

\section{A Philosophy of Communion and Belonging}

O'Donovan (2000, p. 173) has asserted that the social structure of African life makes it elaborate for Africans to understand God's plan for the local church because in Africa a person's extended family and tribal community are the most important realities in his or her life as is incumbent on God's plan for local assemblies becoming the most important community in the life of a Christian. In the examination of the communion ecclesiology, one finds a thin line between it and Ubuntu because Ubuntu is almost similar to togetherness (homothymadon) in the New Testament that connotes Koinonia implying community which is the integral meaning of Ubuntu as stated by (Resane, 2017 p. 105). The congregants of HRM Churches come from different ethnic orientations some of which have harboured long-time hostility in the context of the ethnically polarized society. Integrated into her doctrine is the understanding that in as much as the world is forthright in her advocacy of division along with tribe or ethnicity, Christians once they become members of the communion of the saints experience removal of these bars or walls of hostility and subsequently as is evident in the epistles of the New Testament envisions a community whose communion is with Christ, the source of their identity as is correctly stated by Resane (2017, p. 106).

Ryken (2001, p. 115-119) correctly analyses the community element as is incorporated in the notion of Koinonia as involving not only the sense of belonging to the Christian community but also having an obligation to care for its other members with the understanding that 'what is mine is yours'. HRM Churches are keen to emphasize the essence of community engagement among the congregants through avenues such as the cell church systems and other people groups such as youth ministry, children

7 | This work is licensed under a Creative Commons Attribution 4.0 International License. 
ministry, women ministry, and men ministry as a route to foster this as an internal value. Active participation of all the members is encouraged for all to have that sense of self belonging towards the community. This is in line with the Ubuntu concept in Africa where exclusion from the community is a horrific idea that was tantamount to a death sentence because a lonely person or an excluded person is not a member of the community but a witch as is stipulated by (Nürnberger, 2007, p. 84). Resane (2017, p. 111) has strongly supported the position by the affirmation that it is an emotional suicide and euthanasia to attempt to live outside the community. African ecclesiological conversation cannot be sustained outside the incorporation of the understanding of a church as a community and a Centre of belonging for the congregants. If any church congregation in the territory of the continent of Africa falls short of providing the benefits of a community and a sense of belonging to congregants then it fails in her Ecclesiolatry.

\section{The Philosophy of Communal Human Growth and Development}

The HRM churches believe firmly that if the church is going to move towards the trajectory of having the abundance of God's life, there needs to be a deliberate and conscious effort for a collective and joint growth and development of the entire congregation towards an alignment towards God's will. The traditional African society strongly appreciated the essence of each community member in terms of development and growth. The growth and development of the community member was appreciated as a benefit to the wider community. Yakubu A. Ochefu (2004, p. 9) attributes this to a system of organizing members of the society on the biological concept of age where the grading system was well developed and for one not to know their age group was equated as failure to know one's family. This organized grouping played a critical role in facilitating the educative agenda of the people as was echoed by Obanya $(1999$, p. 137) that members of the same age group were trained at the same time and all candidates were expected to graduate to the next phase of their life together. The age factor was a critical social factor as it was because of the age groups that restricted group members to meddle only in the affairs of their own group unless otherwise authorized.
HRM churches have a firm belief in the corporate growth and development of every member of the church community and that is the reasoning behind the establishment of cell churches that serves as growth group agencies for the purpose of shifting the structure of life in the entire HRM churches to a higher level of spiritual functionality. The growth group principle circulates around the practice of placing members in smaller teams for purposes of growth and functionality. Mutiso-Mbinda (1979, p. 48 ) points out that the model of small Christian communities is based on the primary group level on the concept of a truly fraternal community where the life and communion people have in Christ is deeper, more personal and more intensely shared. This is a ministerial philosophy that prioritizes the essence of the closeness and relationship of church members; active sharing of life; dynamic mutual support; and coordination and encouragement among peers. It is the pursuit of these values that has become an emphasis to the entire leadership to the entire membership of HRM churches in Kenya. Zemale (1992, p. 9) acknowledges that the rationale of small Christian communities is hinged on the understanding of the church as a communion of communities.

This philosophy amplifies the value of sharing divine resources in the life of each one of the HRM membership. Mwana A'Nzeki (1979, p. 292) emphasizes that the building of small Christian Communities is an attempt towards making the communion of God's people a living reality. There is the strong belief that every single member of HRM is a unique package of divine resources for the corporate good of the building of the body of Christ. In these forums, Christians work and pray together as well as share joys and sorrows as captured by (Zemale, 1992). It is the coming together of HRM cell churches that create a vast 'spiritual internet' into which any member of the HRM church can access the necessary resource in the building of the body of Christ. The name of these communities may be small but they are "not so small that there will not be a reflection of the diversity of the gifts of the Spirit, and not so big that the people cannot know one another well' as expressed by (Hearne, $1979 \mathrm{p}$. 23). Integrated into the doctrine of HRM is the awareness that when we find revealed deficiencies in our lives that are fulfilled in the functionality of another, that is God's way of saying to us that part 
of our fulfilment is in the life of another. This deficiency should never be perceived in negativity but must be appreciated as planned and organized to necessitate access to that other resource from other members within the group. Therefore, there is an urgent need for a relational connectivity that facilitates access to the resources in another person.

The essence is that we all need to give access to one another because they have been ordained to live by the resources placed by God in our lives for them. This concept of an ordinance of God within the growth group philosophy creates the distinction with the Basic Ecclesial Community or the Latin America Model that appeared in Brazil in 1956 because their value was based on their involvement in the fight for social justice thus had their origin from below which was the grassroots; but the small Christian communities originates from above, from those whom the mandate of building the kingdom of God has been principally entrusted as is stated by (Mroso, 1995, p. 112). Hearne (1979, p. 23) acknowledges how the early Jerusalem community in Acts is presented as the ideal for the concept of small Christian communities with regard to the koinonia (communion), kerygma (witness and proclamation), and diakonia (service). This is how we participate in the building of the body: by giving this much-needed access to other people to enable them access the resources that God has put in your life. Therefore, the understanding of the completeness of the HRM is in connectivity and access to resources in the lives of other members of the growth group or cell churches. In the same breadth, the inadequacy of every member is completed in a team relationship and thus we should not condemn ourselves for any lack in life. The HRM churches are akin to utilizing the benefit of connectedness and standing alongside one another to facilitate the flow of life and resource within the community. This is because such an arrangement of life will propel us towards the trajectory of a complete and adequate ministerial work.

\section{CONCLUSIONS AND RECOMMENDATIONS}

We can authoritatively affirm that the philosophy of Ubuntu provides African ecclesiology with an efficient technology with regard to the architectural construction of African ecclesiological discoures and discussion that is not only relevant and appropriate to the African setting but responds to the problems of the African people. It is in this understanding of the significance of the Ubuntu philosophy that the HRM Churches has positively embraced the technological know-how by emphasizing an ecclesiological conversation that is people-oriented with regard to offering solutions to the problems of the people and construction of an ecclesiology that is keen to place congregants in the security of a church community in order to enjoy warmth from the haven of a true and genuine sense of belonging. Embedded in the philosophy is the appreciation of the small group as an agency of effective growth and practice of shared life for the benefit of African ecclesiology. This understanding will have a positive impact on the Ubuntu towards African ecclesiology that addresses the problems of Africans and answers their questions. This study recommends for further scholarship with regard to the relationship and impact of Ubuntu and leadership and human development of the congregants.

\section{REFERENCES}

Adeyemo, T. (2009). Africa's enigma and leadership solutions. WordAlive Publishers.

Akinpelu, J. A. (1981). An Introduction to Philosophy of Education- Low-Cost Edition. Macmillan.

Anderson, A., \& Tang, E. (Eds.). (2005). Asian and Pentecostal: The charismatic face of Christianity in Asia (Vol. 3). OCMS.

a'Nzeki, M., \& Ndingi, R. S. (1979). Implementing AMECEA's pastoral priority. African ecclesial review, 21(5), 286-298.

Avis, P. (2019). The Oxford Handbook of Ecclesiology: Oxford Handbooks. Oxford: Oxford University Press.

Barth, K. (2015). Theology and Church: Shorter Writings 1920-1928. Wipf and Stock Publishers.

Bell, R. H. \& Fernback, J. (2015). Understanding African Philosophy: A Cross-cultural Approach to Classical and Contemporary Issues. London: Routledge.

9 | This work is licensed under a Creative Commons Attribution 4.0 International License. 
Chandra, S. S. \& Rajendra K. Sharma. (2006). Philosophy of Education. New Delhi: Atlantic Publishers \& Distributors.

Cowan, S. B., \& Spiegel, J. (2009). The love of wisdom: A Christian introduction to philosophy. B\&H Publishing Group.

Craig, E. (2009). Philosophy: A Brief InsightIllustrated Edition. New York/ London: Sterling Publishing Company.

Dewey, J. (2012). Democracy and Education. Courier Corporation.

Dulles, A. (1974). Church membership as a Catholic and ecumenical problem. The Père Marquette Lecture in Theology Series, 6, 1-112.

Harran, M. J. (1997). Martin Luther: learning for life. Concordia Publishing House.

Hearne, B. (1979). Theology and the Church. AFER 60.

Imbo, S. O. (1998). An introduction to African Philosophy. Lanham/Boulder/ New York/ Oxford: Rowman\& Littlefield.

Jenkins, P. (2002). The next Christendom: the coming of global Christianity. Oxford University Press.

Kärkkäinen, V. M. (2002). An introduction to ecclesiology: Ecumenical, historical \& global perspectives. InterVarsity Press.

Lajul, W. (2014). African philosophy: Critical dimensions. Fountain Publishers.

Masolo, D. A. (1994). African philosophy in search of identity. Edinburgh University Press.

Moll, R. (2006, March 1). Missions Incredible. Christanity Today. https://www.christianitytoday.com/ct/2006/mar $\mathrm{ch} / 16.28 . \mathrm{html}$

Mroso, A. J. (1995). The Church in Africa and the new evangelisation: a theologico-pastoral study of the orientations of John Paul II (Vol. 6). Gregorian Biblical BookShop.
Munyaradzi, M., \& Mubaya, T. R. (2016). African philosophy and thought systems: A search for a culture and philosophy of belonging. Langaa Rpcig.

Mutiso-Mbinda, J. (1979). Pastoral Anthropology and the Church. Eldoret, Kenya: AMECEA Gaba Publications Spearhead 60.

Nürnberger, K. (2007). The living dead and the living God: Christ and the ancestors in a changing Africa. HTS Theological Studies, 64(2 ), 1103-1105.

Obanya, P. (1999). The dilemma of education in Africa. UNESCO Regional Office.

Ochieng, F., Burton, R., \& Brandon, E. (Eds.). (2008). Conversations in philosophy: crossing the boundaries. Cambridge Scholars Publishing.

O'donovan, W. (1996). Biblical Christianity in African Perspective. Paternoster.

Pam, G. D. (2012). A Compendium of Theology. Jos-Nigeria: Sele Printing and Publishing House.

Peck, T. E. (1892). Notes on Ecclesiology- Second Edition. Richmond, VA: Presbyterian Committee of Publication.

Resane, K. T. (2017). Communion ecclesiology in a racially polarised South Africa. Sun Press.

Rosenberg, J. F. (1978). The Practice of Philosophy. New Jersey: Prentice Hall.

Ryken, P. G. (Ed.). (2001). The communion of saints: Living in fellowship with the people of God. P \& R Pub.

Scott, A. S., Netland, H. A., Engen, C. E. V., \& Burnett, D. (2000). Evangelical dictionary of world missions. Baker Books.

Shutte, A. (2002). Ubuntu: An ethic for a new South Africa.

Sung-Hoon Myung, S. H. (2003). Charis and Charisma: David Yonggi Cho and the Growth of Yoido Full Gospel Church. OCMS.

Tempels, P., Rubbens, A., \& King, C. (1959). Bantu philosophy. Paris: Présence africaine.

10 This work is licensed under a Creative Commons Attribution 4.0 International License. 
Volf, M. (1998). After our likeness: The church as the image of the Trinity. Grand Rapids: William B.

Walls, A. F. (2002). The Cross- Cultural Process in Christian History: Studies in the Transmission and Appropriation of Faith. Maryknoll: Orbis Books.

Wonsuk Ma, W., Menzies, W. W., \& Bae, H. S. (Eds.). (2004). David Yonggi Cho: a close look at his theology and ministry. Wipf and Stock Publishers.

Yakubu, O. A. (2004). Ogbu in the Service of his Community. Edwin Ogbu, 62.

Zandberg, J. (2010). The philosophy of Ubuntu and the origins of democracy. Lulu. com.

Zemale, T. J. (1992). Christian witness through small Christian communities. AMECEA Gaba Publ.

11 | This work is licensed under a Creative Commons Attribution 4.0 International License. 